Supplement of Biogeosciences, 17, 5209-5221, 2020

https://doi.org/10.5194/bg-17-5209-2020-supplement

(C) Author(s) 2020. This work is distributed under

the Creative Commons Attribution 4.0 License.

(c) (1)

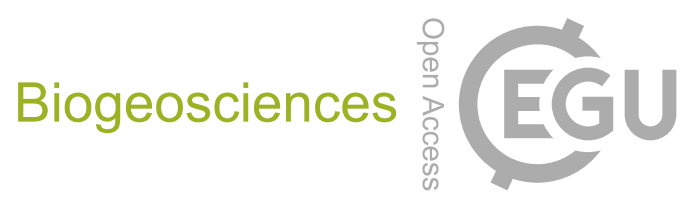

Supplement of

\title{
Methane paradox in tropical lakes? Sedimentary fluxes rather than pelagic production in oxic conditions sustain methanotrophy and emissions to the atmosphere
}

Cédric Morana et al.

Correspondence to: Cédric Morana (cedric.morana@kuleuven.be)

The copyright of individual parts of the supplement might differ from the CC BY 4.0 License. 
Supplementary table and figures.

Table S1. Summary of major limnological characteristics of the sampled lakes. Numbers between brackets are the mean depth; numbers followed by an asterisk are the average value for two sampling cruises. $\mathrm{Zm}$ is the mixed layer depth and $\mathrm{Ze}$ is the euphotic zone depth.

\begin{tabular}{llllllc}
\hline \hline Lake & Mixing regime & $\begin{array}{l}\text { Surface area } \\
\left(\mathrm{km}^{2}\right)\end{array}$ & $\begin{array}{l}\text { Max } \\
\text { depth }(\mathrm{m})\end{array}$ & $\begin{array}{l}\mathrm{Zm} \\
(\mathrm{m})\end{array}$ & $\begin{array}{l}\text { Ze } \\
(\mathrm{m})\end{array}$ & $\begin{array}{l}\text { Chlorophyll } a \\
\left(\mathrm{mg} \mathrm{m}^{-3}\right)\end{array}$ \\
\hline Edward & Monomictic & 2300 & $117(34)$ & $15^{*}$ & $7.7^{*}$ & $4.8^{*}$ \\
Kyamwinga & Monomictic & 2.6 & 40 & 5 & 3.1 & 6.0 \\
Nyamusingere & Polymictic & 3.84 & 3 & 0.5 & 1.1 & 88.3 \\
Katinda & Monomictic & 0.44 & 20 & $1 *$ & $1.2^{*}$ & $77.2^{*}$ \\
George & Polymictic & 250 & $7(3)$ & $0.15^{*}$ & $1.1^{*}$ & $149.7^{*}$ \\
\hline \hline
\end{tabular}



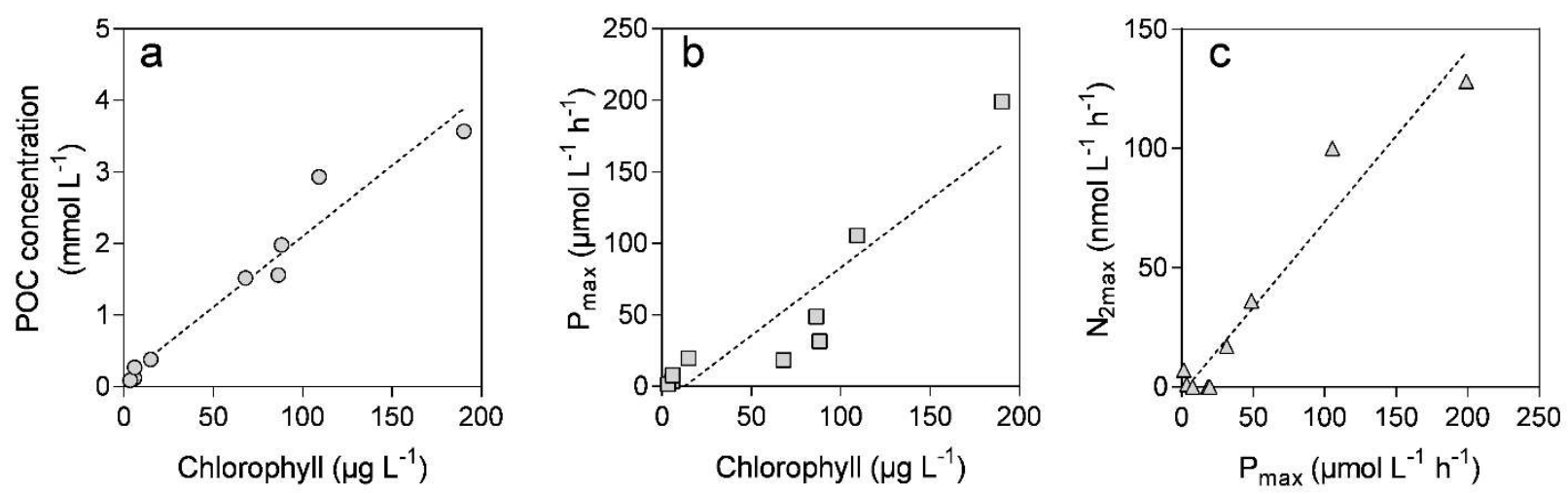

Figure S1. Relationships between phytoplankton primary production and $\mathbf{N}_{\mathbf{2}}$ fixation. Linear relationship between (a) the chlorophyll $a$ ( $\mu \mathrm{g}$ chla $\mathrm{L}^{-1}$ ) and particulate organic carbon (POC, mmol L-1) concentrations, (b) chlorophyll a and maximum photosynthetic activity (Pmax, mmol C L ${ }^{-1} \mathrm{~h}^{-1}$ ), and (c) Pmax and the maximum $\mathrm{N}_{2}$ fixation $\left(\mathrm{N}_{2} \mathrm{max}, \mathrm{nmol} \mathrm{N}_{2} \mathrm{~L}^{-1} \mathrm{~h}^{-1}\right)$ rates. 


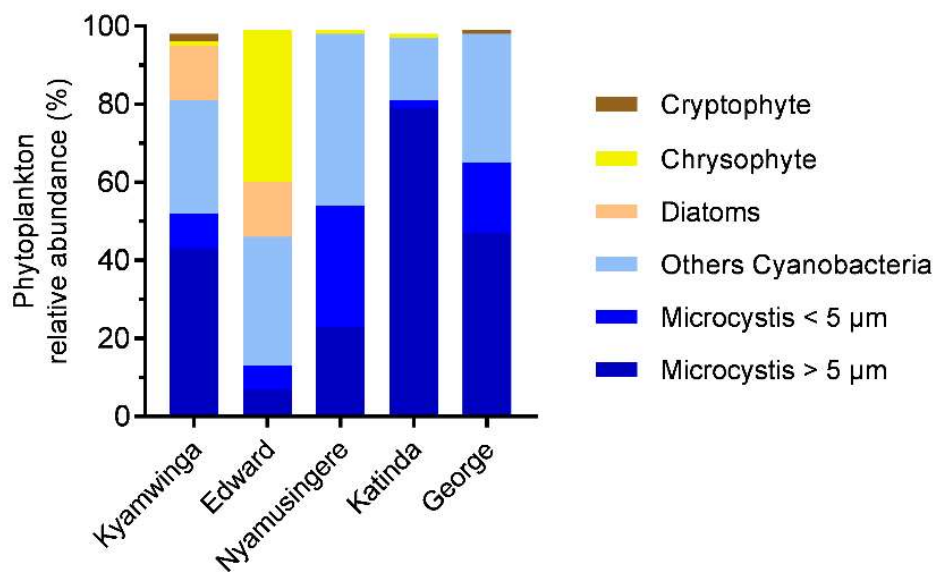

Figure S2. Phytoplankton community composition. Phytoplankton community composition in the surface waters the African lakes sampled. 


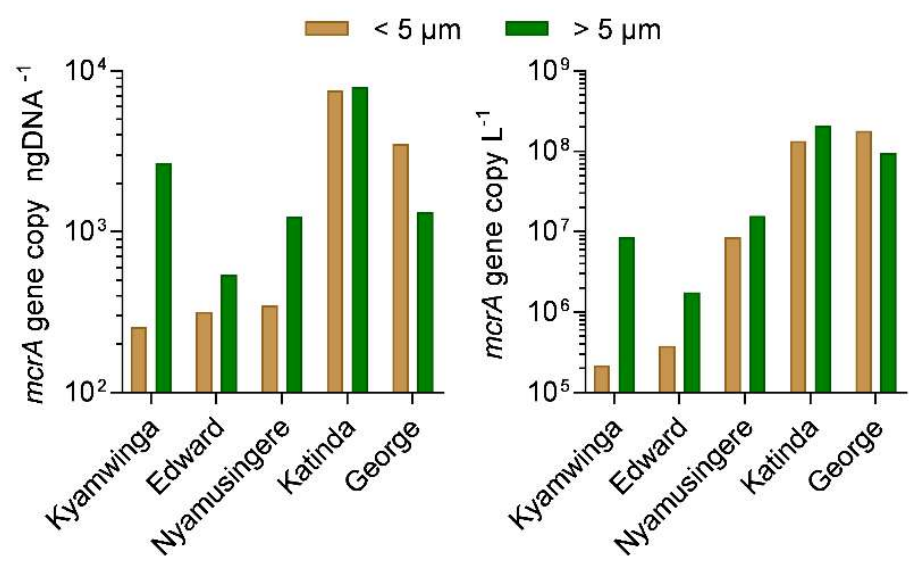

Figure S3. $\boldsymbol{m} \boldsymbol{c r A}$ gene abundance. $m c r A$ gene copy concentration (a) and $m c r A$ gene copy abundance normalized on the DNA concentration (b) in each African lake sampled. Green and brown bars represent the $>5 \mu \mathrm{m}$ and $<5$ $\mu \mathrm{m}$ fraction of the seston, respectively. 


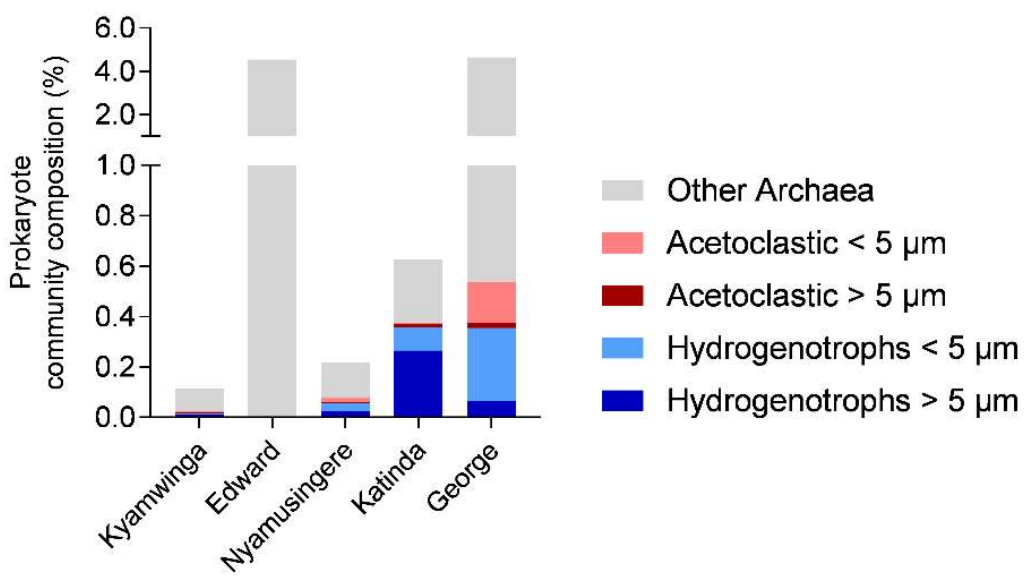

Figure S4. Prokaryote community composition. Contribution of methanogens to the prokaryote community composition in the African lake sampled. 

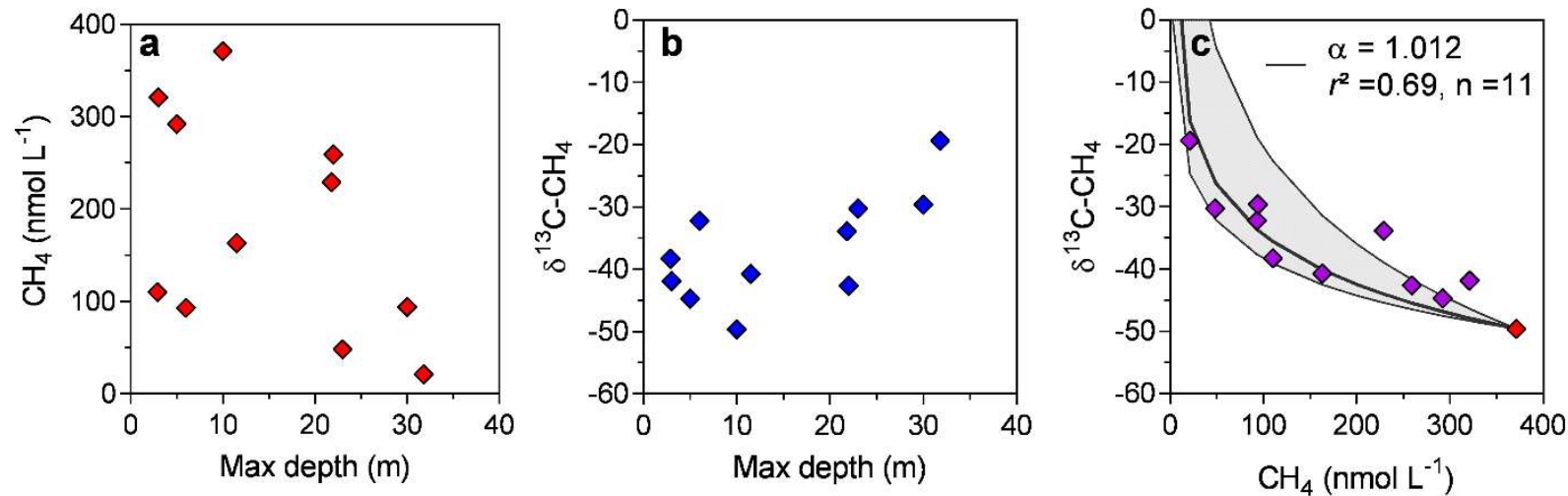

Figure S5. Littoral pelagic - gradient in L. Edward. Relationship between the maximum depth of the station and (a) the $\mathrm{CH}_{4}$ concentration ( $\left.\mathrm{nmol} \mathrm{L}-1\right)$ and (b) the stable carbon isotope composition of $\mathrm{CH}_{4}\left(\delta^{13} \mathrm{C}_{-} \mathrm{CH}_{4}, \%\right.$ ) in surface waters $(0.3 \mathrm{~m})$, in L. Edward. Data were collected between 18/01/2018 and the 24/01/2018. (c) Relationship between the $\mathrm{CH}_{4}$ concentration and the $\delta^{13} \mathrm{C}_{-} \mathrm{CH}_{4}$ in surface waters of $\mathrm{L}$. Edward. The black curve represents the fitted $\left(r^{2} 0.69, \mathrm{n}=11\right)$ apparent carbon isotope fractionation factor during $\mathrm{CH}_{4}$ oxidation $(\alpha)$ calculated as in Morana et al. (2015). Grey zone represents the expected $\delta^{13} \mathrm{C}_{-} \mathrm{CH}_{4}$ at a given concentration considering a range of $\alpha$ value comprised between 1.009 and 1.023 and a littoral (2.5 m max depth) surface water $\delta^{13} \mathrm{C}_{-} \mathrm{CH}_{4}$ source of $-43.6 \%$ (red symbol). The apparent $\mathrm{C}$ isotope fractionation $(\alpha=1.012)$ in L. Edward surface waters was close to the isotope fractionation factor previously determined experimentally for $\mathrm{CH}_{4}$ oxidation in $\mathrm{L}$. Kivu $(\alpha=1.016)$, another large East African lake (Morana et al. 2015). 


\section{$\mathrm{NaH}^{13} \mathrm{CO}_{3}(5 \%$ excess $)$}
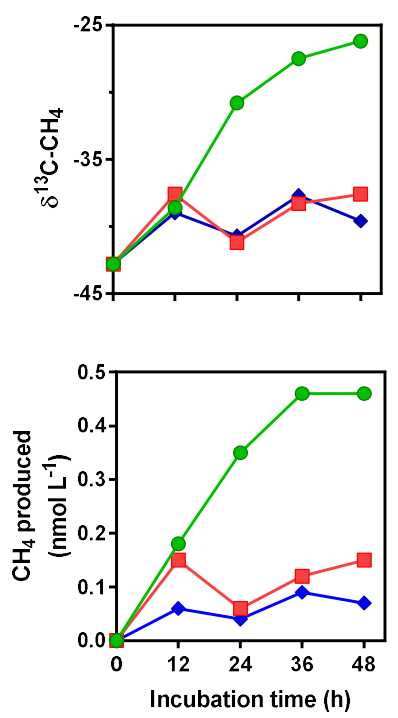

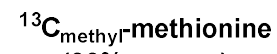

(99\% excess)
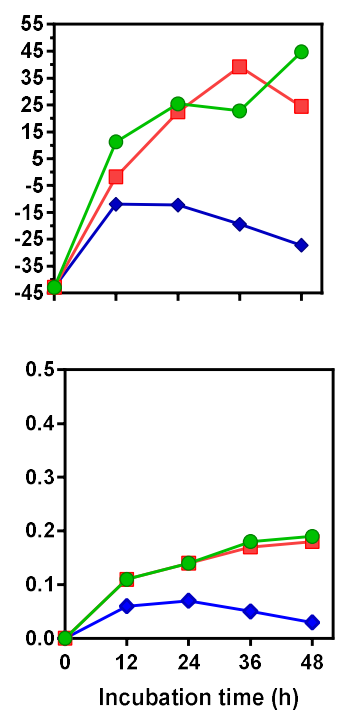

${ }^{13} \mathrm{C}_{1,2}$-acetate

(99\% excess)
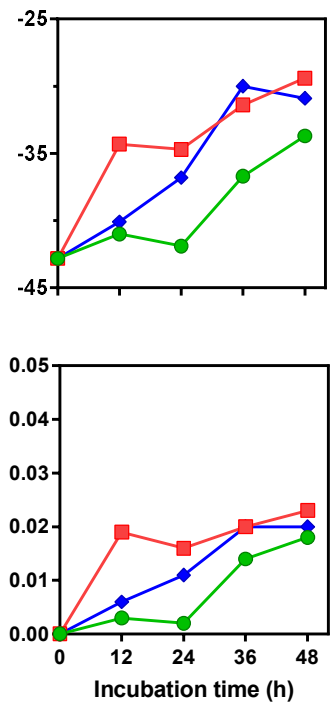

Control

(without ${ }^{13} \mathrm{C}$ tracer)

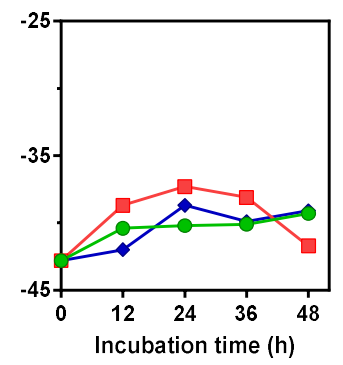

- - Light

$\rightarrow$ Light + DCMU

$\rightarrow$ Dark

Figure S6. ${ }^{13} \mathrm{C}$ labelling experiment kinetics. Upper panel: In well-oxygenated surface waters of Lake Edward, evolution of the $\delta^{13} \mathrm{C}_{-} \mathrm{CH}_{4}$ during the incubation in bottles amended with $1 \mathrm{ml}$ of $\mathrm{NaH}^{13} \mathrm{CO}_{3}$ (leftmost), ${ }^{13} \mathrm{C}_{\text {methyl- }}$ methionine, ${ }^{13} \mathrm{C}_{(1,2)}$-acetate, or water (control treatment, rightmost). Note the difference in the amount of excess ${ }^{13} \mathrm{C}$ between the $\mathrm{NaH}^{13} \mathrm{CO}_{3}$ and the ${ }^{13} \mathrm{C}_{\text {methyl-methionine and }}{ }^{13} \mathrm{C}_{(1,2)}$-acetate treatment. Bottom panel: Amount of $\mathrm{CH}_{4}$ produced from the corresponding $13 \mathrm{C}$-tracer calculated at each time step as described in the material \& methods section. Green, grey and black symbols represent bottles incubated under light, light and DCMU, and darkness, respectively. CH4 concentration $\&{ }^{13} \mathrm{C}$ kinetics showed similar patterns in L. George, L. Katinda and L. Nyamusingere (not showed). 


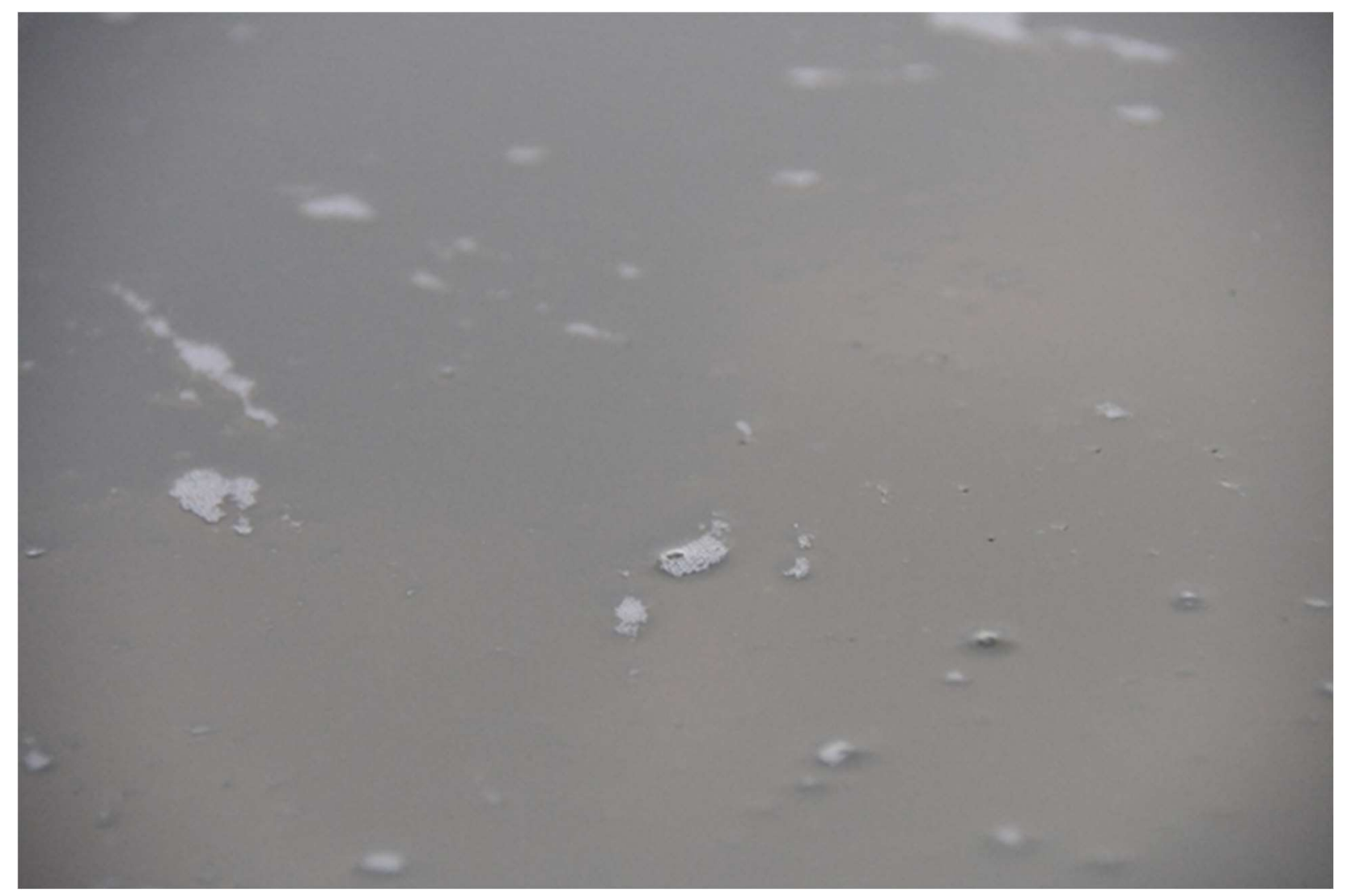

Figure S7. Ebullition in L. George. Picture showing stable bubbles trapped in the organic-rich surface waters of L. George a day of calm weather (28/01/18, sampling at noon). 